Yayın Geliş Tarihi: 24.11.2014

Yayına Kabul Tarihi: 28.04.2015

Online Yayın Tarihi: 31.08.2015

http://dx.doi.org/10.16953/deusbed.97796
Dokuz Eylül Üniversitesi

Sosyal Bilimler Enstitüsü Dergisi

Cilt: 17, Say1: 1, Y11: 2015, Sayfa: 53-66

ISSN: 1302-3284 E-ISSN: 1308-0911

\title{
İŞGÜCÜ PLANLAMASINDA BİR KARAR DESTEK SISTTEMI UYGULAMASI
}

\author{
Y1lmaz GÖKȘEN* \\ Hakan AŞAN** \\ $\ddot{O} z$ \\ Muhammet DAMAR $^{* * *}$
}

Üniversitelerin bünyesinde birçok şirket barınmaktadır. Bu şirketler üzerinde çalışan personeller zaman zaman ara eleman olarak üniversitelerin ihtiyaçlarına dönük birçok noktada istihdam edilmektedir. Personellerin kurum personel sisteminden bağımsız ve el yordamıyla kayıt altına alınması dönemsel hizmet alımiyla süreçlerin ilerlemesi kurumun faydalandı̆̆ iş gücünün doğru şekilde planlanmasını, kontrolünü ve koordinasyonunu yönetim açısından zorlaştırmaktadır. İște bu noktada çalışma üniversite bünyesindeki şirketlerden alınan hizmet alımlarını kaylt altına almakta, iş gücünün planlaması, kontrolü ve koordinasyonu noktasinda bir sistem geliş̧tirmişstir. Gelişen iletişim ve bilișim teknolojilerinden faydalanarak bilgisayar ortamında çallşstrılan karar destek sistemi ve şirket personeli yönetim sistemi, iş gücü planlamasın insanın yapabileceği hatalardan arındirarak nesnel biçimde daha klsa zamanda tanımlayabilmekte ve çözüme ulaştırmaktadır. Kurumun farklı şirketler üzerinden hizmet alımı suretiyle çalıştırdı̆̆g personel saylsının oldukça yüksek olması (yaklașı olarak 1800 çalıșan), işbirliği bütçesinin büyüklüğ̈̈ ve kurum içi ara eleman desteğinin önemi düşünüldüğ̈̈ noktada çalışmanın önemi ortaya çıkmaktadır. Bu çalı̧̧̧ada, iş gücü planlamasında bir karar destek sistemi uygulaması gerçekleştirim süreci açılklanmışıtır. Örneği.

Anahtar Kelimeler: Karar Destek Sistemi, İs Gücü Planlaması, Karar Destek

\section{A DECISION SUPPORT SYSTEM APPLICATION IN WORKFORCE PLANNING}

\begin{abstract}
Many companies are hosted within the university structures. According to the requirements of the universities, employees of these companies are frequently deployed at various realms. Periodic procurement of services and keeping manual records of the employees, independent of the official personal registration system, complicates the

* Doç. Dr., Dokuz Eylül Üniversitesi, İktisadi ve İdari Bilimler Fakültesi, Yönetim Bilişim Sistemleri Bölümü, yilmaz.goksen@deu.edu.tr

** Araş. Gör., Dokuz Eylül Üniversitesi, İzmir Meslek Yüksekokulu, İktisadi ve İdari Programlar Bölümü, hakan.asan@deu.edu.tr

*** Ak. Uzm., Dokuz Eylül Üniversitesi, Bilgi İşlem Daire Başkanlığı, muhammet.damar@deu.edu.tr
\end{abstract}


workforce control and coordination for the institution managers. At this point, this study has developed a workforce planning, control and coordination system by recording the procurement of services supplied by the companies. A computer aided company personnel management and decision support system can provide faster and more objective workforce planning by purifying human errors and using contemporary communication and information technologies. In this study, according to the procurement of services approximately 1800 personnel have been registered and this shows the importance and size of the workforce procurement and a decision support system application development process has been explained. Example.

Keywords: Decision Support System, Workforce Planning, Decision Support

\section{GİRIŞ}

Kurumların başarısında, yöneticiler tarafindan verilen kararların etkisi büyüktür. Kurumların geleceği, verilen bu kararların doğru zamanda verilmesi ve kararların doğruluğu ile yakından ilgilidir. İşletme için en doğru kararı, en kısa sürede verebilmek yöneticilerin birincil öncelikli görevidir. İyi bir kararın niteliği ise, bilgilerin güncel, doğru ve zamanında üretimiyle doğru orantılıdır (Çavuş, 2008: 1-2). Kurumlarda doğru çalışanın kuruma kazandırılması ve doğru şekilde istihdam edilmesi çeşitli kararlar sonucudur. Bu kararların verilebilmesi için performans değerlendirmesi önemlidir. Performans değerlendirmenin sistematik bir şekilde yapılması ve sonuçların kurum içinde değerlendirilmesi, personele geri bildirim yapılması kurum verimliliğini artırmaktadır (Yıldız vd., 2008: 246).

Bilgi toplumunda günümüzün hızla değişen koşullarında, insanı en iyi şekilde yöneten ve geliştiren organizasyonlar başarıya ulaşabilir (Karakaş, 2014: 80). Personelin örgüte bağlılı̆̆ 1 ile örgütlerin varlıklarını sürdürebilmeleri arasında önemli bir ilişki vardır ve kurumlar, varlıklarının devamı açısından çalışanlarını örgüt bünyesinde tutmayı hedeflerler (Yenihan, 2014: 171). Bu noktada personelin doğru yerde, doğru iş sürecine entegre edilmesi önemli olmaktadır. Ünnü ve Keçecioğlu'na göre (2009: 1180) günümüzde örgütler sahip oldukları nitelikli insan kaynakları ve bu kaynakları ellerinde tutabilme düzeylerine göre hayatta kalabilmekte ve rekabetçi avantaj kazanabilmektedirler.

İş yaşamında verimsizlik ve düşük üretkenlikle karşılaşılmasının nedeni, o işin yapılması ile ilgili niteliklere sahip çalışanların bulunamaması ya da çalışanların yetenekleri, eğitimleri dışında işlerde görevlendirilmeleridir. Çalışma bu noktada, üniversiteler içerisinde çeşitli şirketler üzerinden çalıştırılan insan kaynaklarının doğru bir şekilde koordinasyonu, planlanması ve yönetimini sağlayan bir karar destek sistemi süreci gerçekleştirmiş ve Dokuz Eylül Üniversitesi bünyesinde sözleşmeli olarak, hizmet alım yolu ile tahsis edilen iş gücünün planlanması, kayıt altına alınması ve doğru personelin doğru iş ile buluşturması için ilgili süreçleri oluşturmuştur. 


\section{ÇALIŞMANIN AMACI}

İnsan kaynaklarını doğru bir şekilde yönetmek ve doğru iş gücünü doğru yerde kullanabilmek işletmeler için çok önemlidir. Bu durum; iş süreçlerinin, bilgi teknolojileri ile doğru bir şekilde koordine edilmesiyle gerçekleştirilebilir. İşgücü planlaması ve insan kaynaklarından maksimum seviyede fayda sağlayabilmek işletmeler için ortak bir amaçtır. Ekinci (2008: 175), bir kurumdan beklenen verimin elde edilmesi için kurum çalışanlarını temel faktör olarak belirtmektedir, ayrıca insan kaynaklarını bir kuruluşun en önemli ve değerli varlığı olarak görmektedir.

Bir işletmede, personelin işe alımından çıkarılmasına kadar her aşamayı yöneten birim insan kaynakları birimidir (Küçükönal ve Korul, 2002: 69). Üniversitelerde bu birim "Personel Daire Başkanlıkları" olarak karşımıza çıkmaktadır. Personel seçim süreci, insan kaynakları uygulamalarının sağladığ 1 katkılar göz önüne alındığında; geri dönüşü en hızlı, ekonomik katkı açısından en yüksek olan ve kolaylıkla gözlemlenebilen süreç olma özelliği taşımaktadır.

İşverenler ihtiyaç ve kurum hedeflerine dönük personellerinin performanslarını, işe başlama zamanından itibaren gözlemleme imkânına sahiptir. İşveren için işe alınacak personelin yetenekleri yapılacak işin ve görevlerin arasında işlevsel bağlantıyı kurmak, personel adayları arasında işe en uygun nitelikteki personeli belirlemek insan kaynakları biriminin temel görev ve sorumlulukları içerisinde yer almaktadır (Filizöz, 2003: 162).

Şekil 1: Şirket Personeli Hizmet Alım Eski İş Süreci
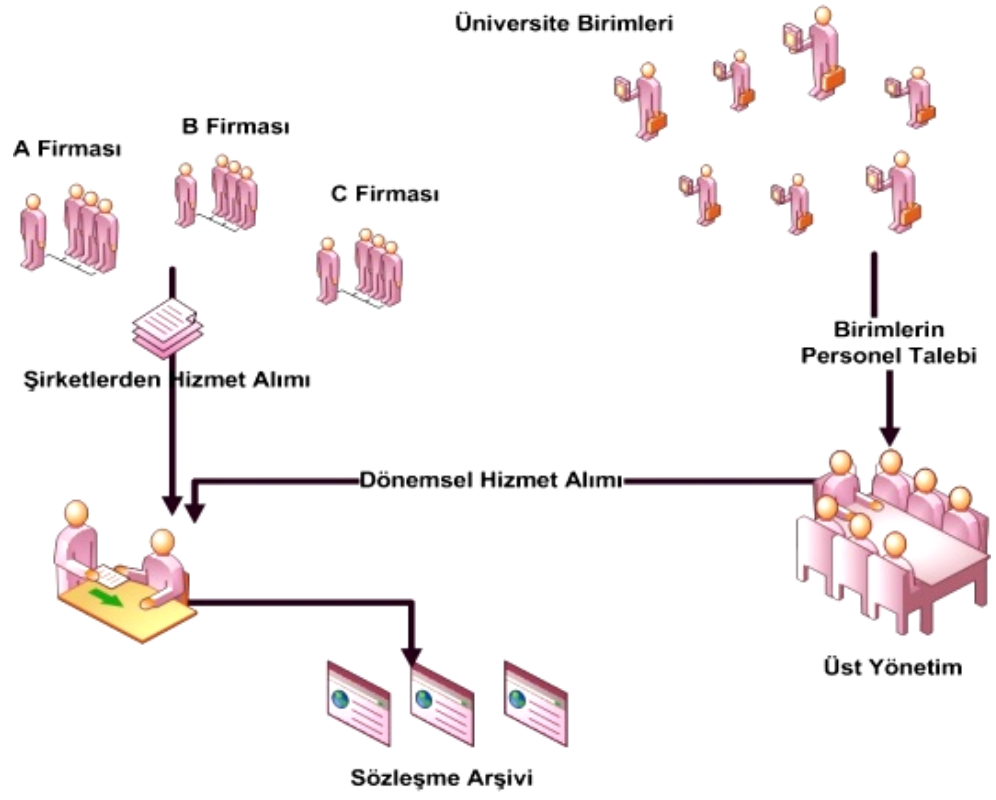

Ôst Yönetim 
$\mathrm{Bu}$ noktada üniversitelerin iş gücünde önemli bir yere sahip olan sözleşmeli personelin performansından doğru bir şekilde faydalanabilmek, gerçekleştirilen karar destek sisteminin amacıdır. Türkiye'de birçok üniversite ara eleman istihdamını şirketler üzerinden hizmet alım süreciyle gerçekleştirmektedir. Üniversitelerde ara eleman olarak istihdam edilen personelden konum olarak kafeteryalarda, bilgi işlem birimlerinde, hastanelerde vb. birçok lokasyonda istihdam edilmekte; hizmetli, laborant, güvenlik görevlisi vb. pozisyonlarda iş gücünden faydalanılmaktadır. Şekil 1 üzerinde çalışma öncesinde şirketler üzerinden gerçekleşen hizmet alımının süreçleri gösterilmiştir.

\section{KARAR DESTEK SİSTEMI}

Bilgi teknolojileri, hız, bilgi hacmi ve süreç kapasitesi açısından karar almaya destek sağlayan bilgi tabanlı araçlardır. Kurum içi örgütsel ve yönetsel etkinliği gerçekleştirebilmek için bilginin etkin yönetilmesi gerekmektedir (İnce ve Oktay, 2006: 16-17). Karar vericiler, bilgi, muhakeme, sezgi ve deneyimlerini karar almaya yansıtmak için bilgi teknolojilerine ihtiyaç duyarlar. Bilgi teknolojileri, bu aşamada, karar vericilere büyük kolaylık sağlar. Ancak, karar verici bilgiyi elde etmek için ne tür soruları sormak gerektiğini ve soruların cevapları için bilgi sürecinin nasıl işleteceğini bilmesi gerekir. Karar Destek Sistemleri (KDS), karar vericiler için yarı yapılandırılmış durumlar ve yapılandırılmamış durumları için veya karar verilecek yönün kestirilemediği ve bulanık olduğu durumlarda, karar verenlere modeller sunan, karar durumu ile ilgili bilgiler sağlayan ve verinin yönetimi için araçlar sunan etkileşimli bilgi sistemleridir (Alter, 1999: 173). Karar destek kavramı; yönetici kademesindeki kişilerin, yönetsel problemlerini oluşturulan bir model ile çözümleme çabası neticesinde ortaya çıkmıştır (Özsever vd., 2009). Karar destek sistemleri verilmesi istenen karar ile ilgili veriyi algılayıp anlayarak etkin karar seçenekleri oluşturmaktadırlar. KDS'ler alternatif kararlar belirleyerek ve olası kararları değerlendirerek karar süreçlerine destek sağlamaktadırlar (Türkiye Bilişim Derneği, 2010: 5). Karar destek sistemini oluşturan ana bileşenler, karar destek sistemi veritabanı, karar destek sistemi yazılım sistemi ve kullanıcı ara yüzü şeklindedir (Gökçen, 2011: 75).

Koçel'e göre herhangi bireyin yönetim kademesinde olsun veya olmasın kişinin herhangi bir konuda yaptığı seçme işlemine "karar"dır. Bu durumda tercih etme, tercih edilen durumunu benimseme ve karar verme bir biriyle yakından ilişkilidir. Koçel bu konuda seçim yapılamıyorsa kaynakların ne için ve nasıl kullanılacağ 1 bilinemiyor demektedir ve karar vermeyi bilgiyi işlemek olarak adlandırmaktadır (Koçel, 2013: 109). Mintzberg, yöneticilerin günlük davranışlarını analiz ederek literatüre "yönetici rolü" kavramını sunmuştur. Yönetsel roller, yöneticilerin bir örgütte yerine getirmesi gereken faaliyet beklentileridir ve bu roller bireyler arası, enformasyona ilişkin ve kararlara ilişkin olmak üzere üçe ayrılır (Rüzgar ve Kurt, 2013: 38). Yöneticinin enformasyona 
ilişkin rolü incelendiğinde yöneticiler, en somut, güncelleştirilmiş enformasyonu alarak ve ona ihtiyaç duyanlara tekrar dağıtarak, örgütlerin komuta merkezi gibi hareket ederler (Laudon ve Laudon, 2011: 459).

$\mathrm{Bu}$ açıklamalar odağında yöneticilerin karar alma süreçlerini kolaylaştırıcı bir sistem olarak, karar destek sistemleri karşımıza çıkmaktadır. Şekil 2 üzerinde karar destek sisteminin bileşenleri görülmektedir.

Şekil 2: Karar Destek Sistemi Bileşenleri

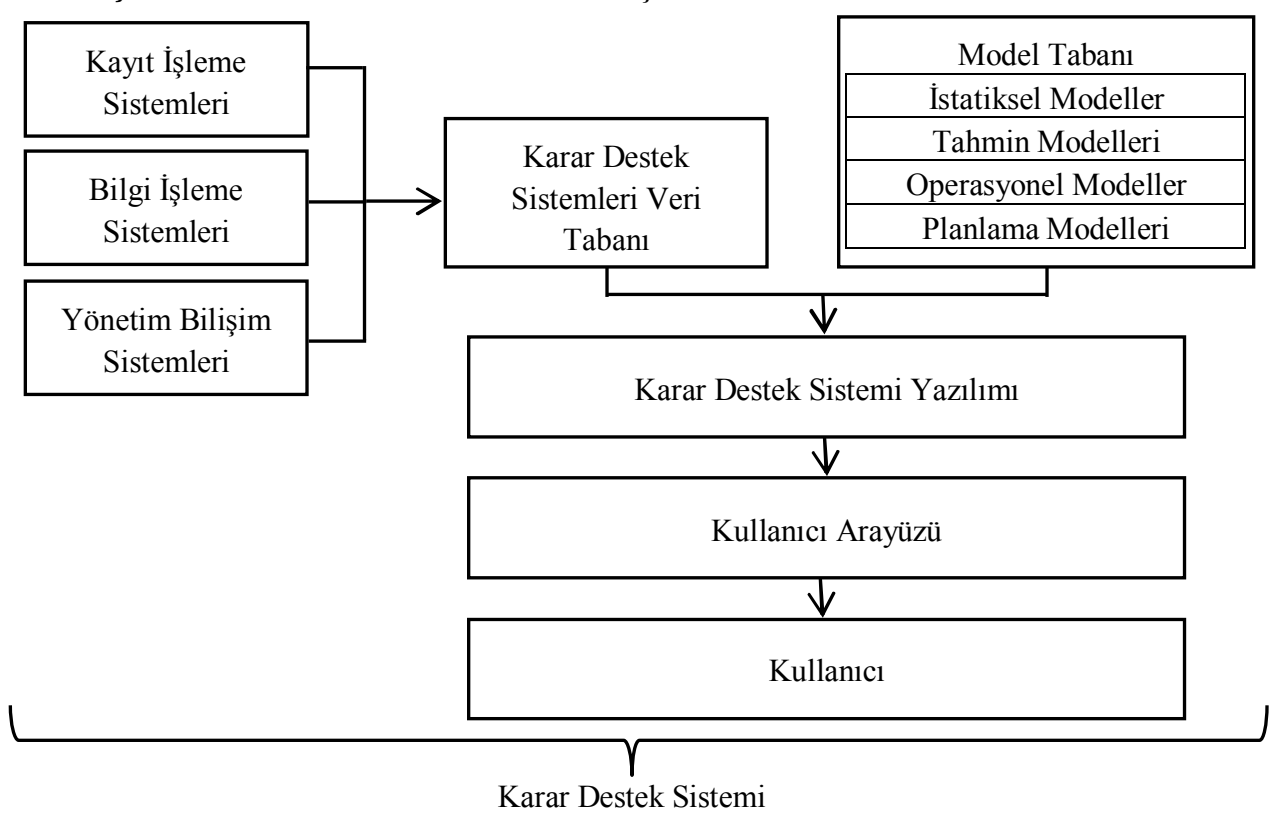

Kaynak: Organizasyonel karar destek sistemleri ve organizasyonel kararlarda bilişim sistemlerinin uygulanmasına ilişkin bir araştırma. Yayınlanmamış Doktora Tezi. Marmara Üniversitesi, Sosyal Bilimler Enstitüsü, İstanbul, s. 55.

Karar destek sistemleri, yazılım ve donanım ile bütünleşmiş bir bilgi sistemi olmasının getirdiği özellikle bilginin üretimi ve sunumu için kullanıcı ile etkileşerek oluşan bilgi sistemleridir. Bu sistemler; karar vericilere veri sağlama, üretme, erişme, veriyi analiz ederek bilgiye dönüştürme ve karar alternatifleri oluşturma gibi işlemleri yazılımla sunarak; karar sürecinin her aşamasında onlara destek sağlar ve süreci hızlandırır.

Bir karar destek sisteminin temel özellikleri şunlardır (Çetinyokuş ve Gökçen, 2002: 45-46):

- Yar1-yapısal ve yapısal olmayan durumlarda karar verme süreçlerinde kullanılmaktadır.

- Karar verenin yerini almak amaciyla değil aksine karar vericinin karar vermesine yardımcı olmak amaciyla oluşturulan sistemlerdir.

- Karar vermek bir süreçtir ve bu sürecin tüm adımlarını destekleyicidir. 
- Karar vericinin yani karar destek sistemini kullanan kişinin kontrolündedir.

- Karar destek sistemleri bir model kullanmaktadır.

- Karar verici ile etkileşim içindedir.

- Organizasyonun tüm aşamalarındaki yöneticileri için, ihtiyaç duyulduğunda aşamalar arası entegrasyonu da göz önüne alarak karar vermeyi desteklemektedir

- Bağımsız veya bağımlı kararlar için destek sağlamaktadır.

- Grup tabanlı veya bireysel olarak karar verme desteği sağlamaktadır.

- Uygulamalar için kolaylık ve esneklik sağlamaktadır.

\section{ISS GÜCÜ PLANLAMASINDA KDS}

Kurumlara işgücü istihdam etmek stratejik bir karar noktasıdır ve işgücü verimliliği ölçülmesi ve yönetilmesi gereken önemli bir performans ölçütüdür. Personeli doğru noktada maksimum verimi alacak şekilde istihdam edilmesi iş ile personelin doğru bir şekilde algılanmasıyla ortaya çıkar. Ne tür işlerin yapılacağı, bu işleri yapacak kişilerin sahip olması gereken nitelikler, kişisel veya grup halinde çalışma, çalışılacak personelin işletmenin hangi noktasında çalışacağ etmenlerden etkilenebilir. Doğru kişinin doğru yerde istihdam edilmesi personel motivasyonuna artırır; bu durum iş yerindeki verimliliği artırmaktadır.

Karakütük'e göre (1997: 118) planlama, bir yönetim süreci olmakla beraber tüm yöneticilerin yapması gereken bir etkinliktir. Etkin insan sermayesi oluşturamayan ve yönlendiremeyen örgütler için rekabetçi avantajı oluşturması ve sürdürmesi olanaksız görülmektedir (Keçecioğlu ve Oktay, 2010: 68). İşletmeler için üretim potansiyellerinin sınırlarını zorlayabilmeleri ve işletmelerin rakipleri karşısında rekabet üstünlüğü sağlayabilmeleri, kurum içinde nitelikli iş görenlerin istihdam edebilmeleri ile yakından ilişkilidir. Bunun yanında işletmelerin istihdam ettikleri nitelikli iş gücünün sürdürülebilirliği ve iş görenlerin potansiyellerinden maksimum seviyede faydalanabilmelerine de bağlı olduğu anlaşılmıştır (Alayoğlu, 2010: 28).

Çalışma, kurum içindeki sözleşmeli personelin iş gücü planlanmasını kayıt altına alan bir süreç oluşturmuştur. Oluşturulan sistem ile üst yönetim için sözleşmeli personelin iş gücü planlamasındaki kararlarına destek oluşturmaktadır. Kamu sektöründe birçok kurum iş süreçlerinde sözleşmeli personel istihdam etmektedir. Bu personel grubunun iş gücü planlamasında oluşturulan karar destek sistemiyle diğer kurumlara örnek teşkil edebileceği düşünülmektedir.

Kayıt altına alınan iş gücü dikkate alındığında; süreçte yaklaşık 1800 personel kayıt altına alınmış ve askeri ücretin kiși başı 891,03 TL olduğu görülmektedir. Bu veriler 1şığında personel sayısı ve minimum personel ödemesi dikkate alındığında: 1800 (personel sayısı) x 891,03 (aylık asgari ücret miktarı) = 1.603.854 TL'lik bir rakama ulaşılmaktadır. Kurum için işveren maliyeti dikkate alındığında personel başına işveren maliyeti (TL/AY) 1134,00TL şeklindedir 
(http://www.csgb.gov.tr/csgbPortal/cgm.portal?page=asgari, 18.09.2014). Sistemde kayıtlı personel sayısını 1800 olarak aldığımızda 1800 (personel sayısı) x 1134,00 (işverene maliyeti) $=2.041 .200 \mathrm{TL}$ üniversite için bir maliyet oluşturmaktadır. $\mathrm{Bu}$ hesaplamalar minimum asgari ücret üzerinden hesaplanmıştır. İstihdam edilen personel sayısı ve kurum için yaratmış olduğu maliyet hesap edildiğinde ciddi bir rakam ortaya çıkmaktadır. Bu noktada, kuruma büyük miktarda maliyeti olan iş gücünü doğru bir şekilde planlamak, koordine edebilmek ve etkin yönetebilmek için karar destek sistemi oluşturulmuştur.

\section{İNSAN KAYNAKLARI FONKSIYONLARI AÇISINDAN KARAR DESTEK SISTEMI}

Geliştirilen iş gücü planlama karar destek sisteminde veriler yıllar bazında toplanabilmekte, oluşturulan modeller ve algoritmalar ile değerlendirilerek ve geleceğe yönelik tahminler karar süreçlerine destek amacıyla kullanılmaktadır. Sözleşmeli personel üniversite personelinden ayrı bir noktada iş gücü olarak görülmektedir. Kamu kurumlarında insan kaynakları yönetiminden daha çok personel yönetimi şeklinde bir anlayış hüküm sürmektedir. $\mathrm{Bu}$ da iş gücünün etkinliğini ve kontrol altına alınmasını kurumlar tarafından bunun sahiplenilmesini engellemektedir.

Tablo 1 incelendiğinde, insan kaynakları fonksiyonları açısından, proje veritabanı üzerinde tutulan verilerin örtüştüğü açık bir şekilde görülmektedir. Örneğin iş gören bulma ve seçme noktasında birim ve birime bağlı personellerin görülebilmesi; birimin açık ve kapalı alanının veri tabanına işlenmesi, iş gören bulma ve seçme noktasında bize veri sağlamaktadır. Ayrıca birim üzerinde çalışan sözleşmeli personel sayısını kayıt altına almamız, kurum içi iş gücü planlamamızı, doğru bir şekilde gerçekleştirmemizi sağlar. İşgücü planlaması insan kaynaklarının en önemli fonksiyonudur.

Tablo 1: Karar Destek Sistemi Parametrelerinin İK Fonksiyonları Açısından Değerlendirilmesi

\begin{tabular}{|c|c|}
\hline $\begin{array}{c}\text { İnsan Kaynakları Yönetiminin } \\
\text { Başlıca Fonksiyonları }\end{array}$ & $\begin{array}{c}\text { Karar Destek Sisteminde Tutulan Verilerden } \\
\text { Bazıları }\end{array}$ \\
\hline $\begin{array}{ll}\text { - } & \text { İnsan kaynaklarının planlanması } \\
\text { - } & \text { İş gören bulma ve seçme } \\
\text { - } & \text { İnsan kaynaklarının geliştirilmesi ve eğitimi } \\
\text { - } & \text { İş gören sağlık ve güvenlik yönetimi } \\
\text { - } & \text { İş gören performans ölçümü ve değerlendirilmesi } \\
\text { - } & \text { İş gören ücretlendirme yönetimi } \\
\text { - } & \text { İş görenler arasındaki çalışma ilişkilerinin } \\
& \text { biçimlendirilmesi ve organizasyonun endüstriyel } \\
& \text { ilişkilerin şekillendirilmesi }\end{array}$ & $\begin{array}{ll}\text { - } & \text { Personelin Yaşı } \\
\text { - } & \text { Çalışma Süresi } \\
\text { - } & \text { İkamet Ettiği Yer } \\
\text { - } & \text { Aldığı Ücret } \\
\text { - } & \text { Cinsiyeti } \\
\text { - } & \text { Çalıştı̆̆ Birim } \\
\text { - } & \text { Çalışllabilecek Birimler } \\
\text { - } & \text { Birimlerin Alan Ölçüleri } \\
\text { - } & \text { Birim Açı Alan, Kapalı Alan vb. }\end{array}$ \\
\hline
\end{tabular}




\section{KDS TASARIM VE GELIŞTİRME SÜRECİ}

Yöneticiler, görevleri gereği sürekli kararlar almak durumundadırlar. Ancak etkin sonuçlar alınabilmesi için alınan kararların zamanında, tutarlı ve doğru olması gerekmektedir. Etkin sonuçlar için gerekli kararların alınmasında bilgiye ihtiyaç duyulur. Bilginin ise mevcut verilerden üretilmesi gerekmektedir. Karar verici bilgileri araştırıp analiz ederken ve sonuçlarını değerlendirmeye çalışırken çok vakit kaybeder. Şekil 1 üzerindeki şirket personeli hizmet alım eski iş süreci yer almaktadır. Süreç içerisinde üst yöneticiye rapor verme, hizmet gereksinimlerinin temini, birimlerin ihtiyaçlarının kayıt altına alınması ve koordinasyonu noktasında çalışan bir sistemin varlığından söz etmek güçtür.

Şekil 3: Şirket Personeli Hizmet Alım Yeni İş Süreci

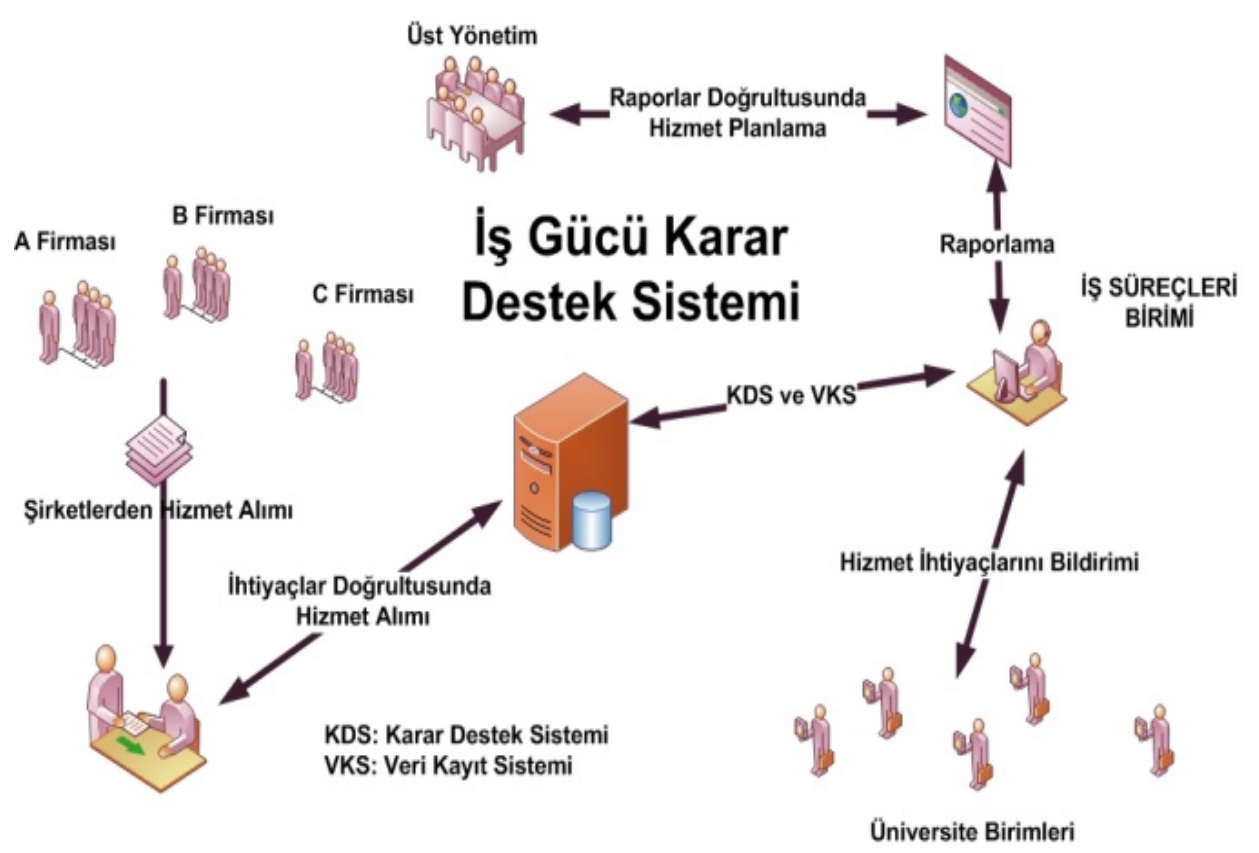

Hizmet alım noktasında; ne zaman, hangi ihtiyaca yönelik uygun personel tedarik edilecek gibi sorulara cevap vermek, yönetsel belirsizlikler nedeniyle süreç açısından çok zor ve çok zaman alıcı görünmektedir. Bu zaman kaybı ve süreçlere hâkimiyetin zorluğuna Şekil 3 üzerinde gerçekleştirilen süreçler ile çözüm bulunmuştur. Hizmet alım sürecinin tüm aşamaları sistematik olarak ele alınmıştır. Birimlerin hizmet taleplerinin koordinasyonu sağlanmış, bu talepler çeşitli parametre ve algoritmalara göre tutulmuş, üst yönetimin bu noktadaki talepleri doğrultusunda hızlı bir şekilde raporlanabilir hale getirilmiştir. 
Şekil 4: SQL Server 2012 Üzerinde KDS Projesi Tablo ve Kayıtların Görünümü

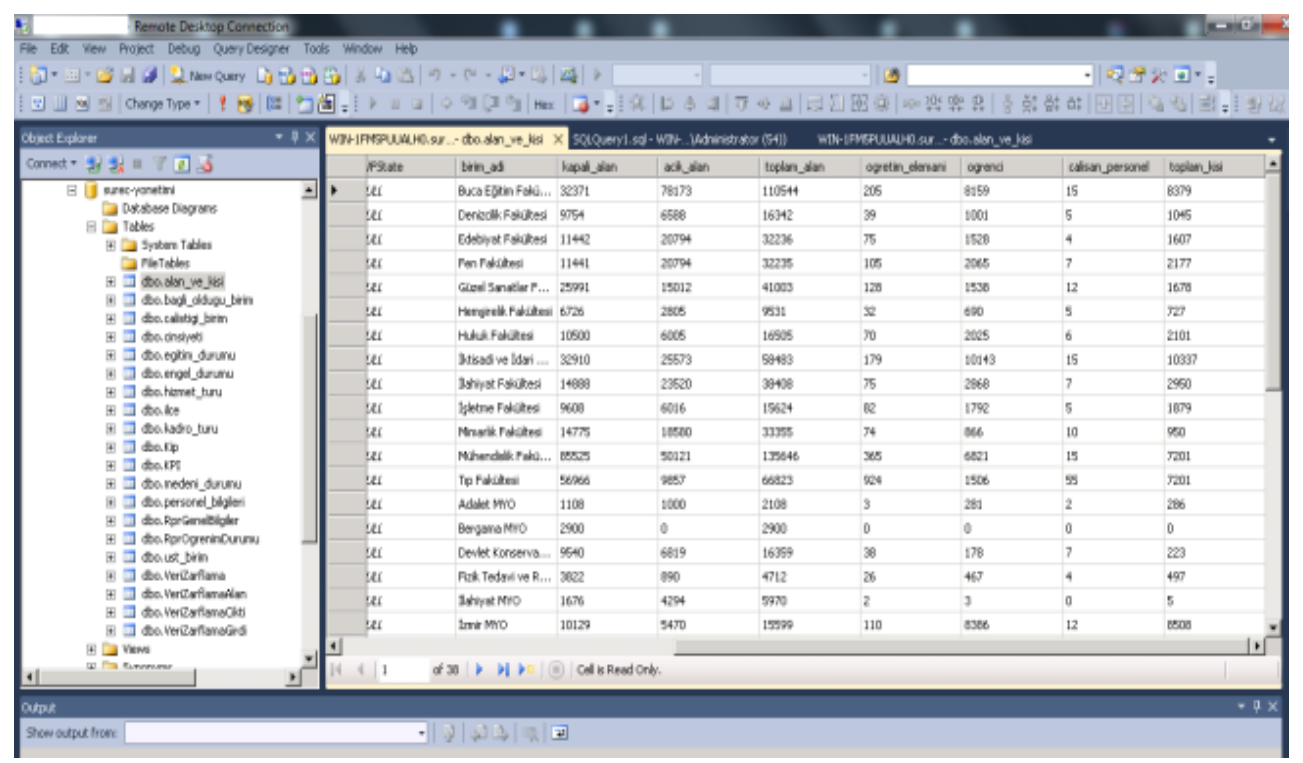

$\mathrm{Bu}$ noktada yöneticiler hizmet alım sözleşmesi ile istihdam edilen personelin hangi birimde hangi işte çalışacağı noktasında geliştirilen sistem sayesinde veriye erişebilmektedir. Birimlerin özellikleri ve personellerin özellikleri parametrik olarak proje veri tabanında tutularak ve çeşitli parametreler ve algoritmalar ile listelenerek yöneticiye personelin doğru yerde çalıştırılması için seçim şansı vermektedir. Yöneticinin iş gücü planlamasında, koordinasyonunda ve kontrolünde sözleşmeli personeli Şekil 3'de görüldügüü üzere İş Gücü Karar Destek Sistemi kayıt altına almış ve süreçleri dijitalleştirmiştir. Yöneticinin karar verme sürecinde ihtiyaç duyduğu alternatifleri sunarak karar vericiye destek sağlayan bir sistem ortaya koymuştur.

\section{GERÇEKLEŞTİRILEN PROJENIN KAZANIMLARI}

Gerçekleştirilen iş gücü karar destek sistemi analiz ettiği problemin isterlerine dönük karar destek sistemini kullanarak sonuç raporlarından veya tablo analizlerinden yola çıkarak, olası çözümler içerisinden en uygununu bulma noktasında yöneticilere hizmet vermektedir.

Gerçekleştirilen projenin kazanımları:

- Hizmet alım süreçlerinde karar vermeyi kolaylaştırıcıdır.

- Veri tabanı üzerindeki tablolar üzerindeki veriler insan kaynakları fonksiyonunu destekler durumdadır. 
- Kurum içerisinde bilgi sistemleri arasında köprü görevi görebilir ve diğer sistemler ile konuşabilir, bilginin sayısallaştırılmasında, taşınmasında ve paylaşılmasını sağlar.

- Web platformunu kullanması nedeniyle, html 5 ile uyum gösteren tüm cihazlar ile kolayca ulaşılabilmektedir.

- Farklı lokasyonlardan, farklı cihazlar ile internete açık her noktada projeye ulaşılabilir ve imkânlarından faydalanır.

- Süreçler üzerinde kontrol, denetim, süreçleri anlık izleme imkânı ve süreçlerin raporlanması ile işlerin hatasız ilerlemesi sağlanmaktadır.

- Oluşturulan yeni süreç vasıtasıyla üst yönetime birimlerin ihtiyaçları, çalıştırılan personel sayısı, bütçeye etkisi vb. raporlar sağlar (Şekil 5).

- Farklı bilgi sistemler ile bütünleşebilen çözümler üretilebilir, hızlı ve etkin şekilde süreçler oluşturulabilir.

- Bilginin denetimi oluşturulan sistem ile bilgi güvenliği ve bilginin paylaşımı tek bir konumdan yapılabilir.

- Organizasyon içinde sayısal ortama taşınan verilerin sağladığı imkân sayesinde süreçlerdeki verimlilik ve izlenebilirlik artışı sağlanmaktadır (Şekil 6).

- Sözleşmeli iş gücü üzerinde diğer birimlere veri sağlama, raporlama kolaylaşır ve yöneticilerin etkin karar verme gücü artar (Şekil 7).

- Tüm bu özellikler ile kurumun sözleşmeli personelden doğru bir şekilde faydalanılması sağlanır, gereksiz hizmet alımının önüne geçilir, sözleşmeli personel istihdam maliyetleri düşer ve servis/hizmet kalitesi artar.

Şekil 5: Birimlere Göre Personel Dağılımı

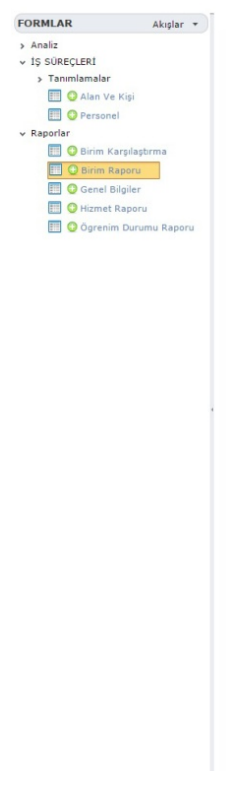

Birimlere Göre Personel Sayısı

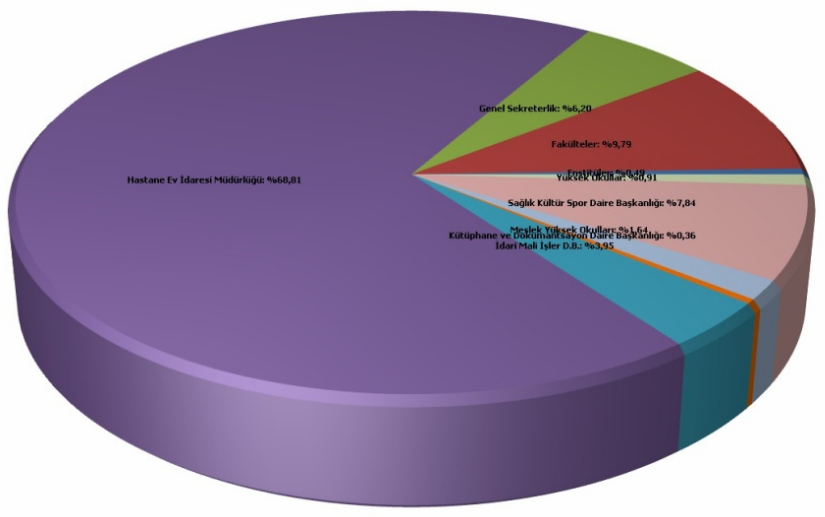


Şekil 6: Üniversitenin Birimleri Bazında Karşılaştırmalı Personel Sayıları
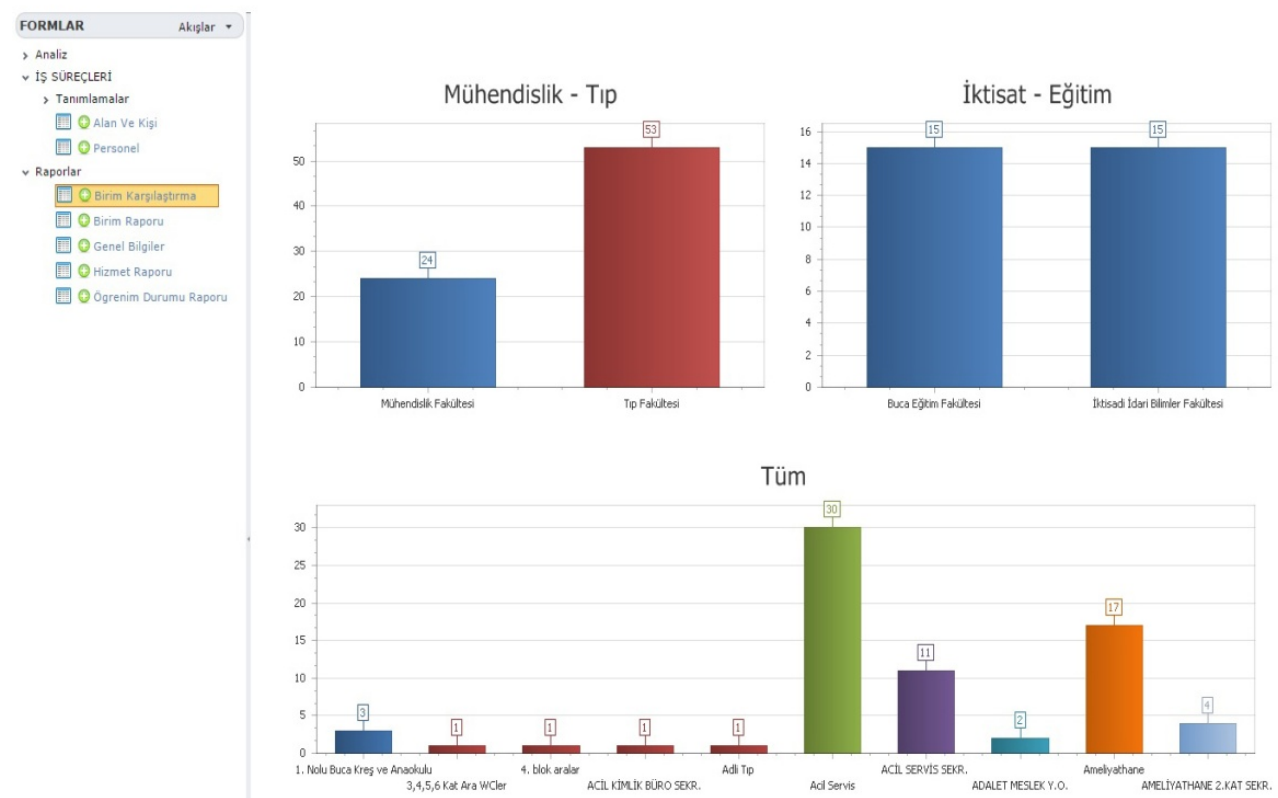

Şekil 7: Personele Ait Genel Bilgiler

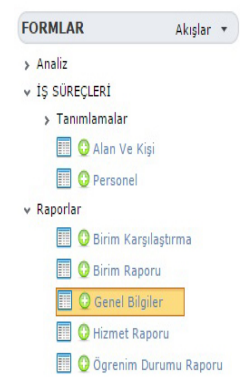

Cinset Dağlımı

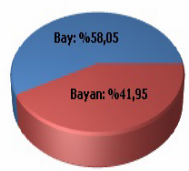

Engelli Durumu

Medeni Durumu
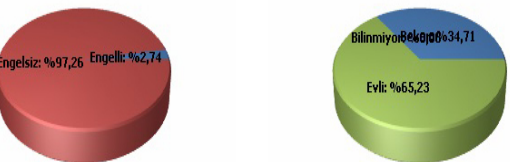

Eğitim Durumu Dağı̆ım

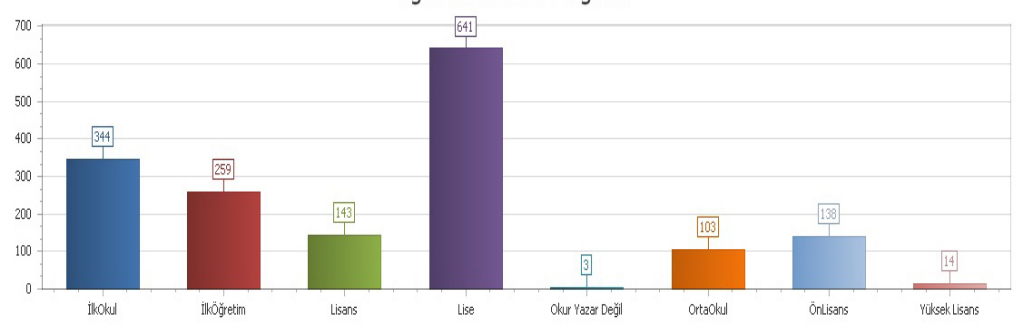


Gökșen, Y., Așan, H., Damar, M.

DË̈ SBE Dergisi, Cilt: 17, Sayl: 1

\section{SONUÇ VE DEĞERLENDİRME}

Çalışma Dokuz Eylül Üniversitesinde, hizmet alımı yolu ile çeşitli şirketler üzerinden istihdam edilen personeli kayıt altına alarak, ilgili personelin iş gücünün etkin kullanımı ve yönetimi noktasında karar destek süreci oluşturmuştur. Çalışma öncesinde süreçler, birimlerin asenkron şekilde personel taleplerini üst yönetime iletmesi ve ihaleler vasitasıyla, isteğe bağlı dönemlerde hizmet alım süreçleri gerçekleştirilmiştir. Bu süreçler birçok kamu kurumu ve diğer üniversitelerde aynı şekilde gerçekleştirilmektedir. Geliştirilen iş gücü karar destek sistemi ile bu hizmet alımı dijitalleştirilmiş, iş gücü kayıt altına alınmış, doğru personelin doğru noktada çalıştırılabilmesi noktasında çeşitli parametreler vasıtasıyla çalışan algoritmalar ile iş gücünün doğru noktada doğru bir şekilde kullanılması sağlanmıştır. Geliştirilen iş gücü karar destek sistemi bu noktada diğer kurumlara örnek oluşturmaktadır. Ayrıca kurum içinde hizmet alım yoluyla alınan personelin çok değişken bir yapıda olması, sık sık değişimlerin gerçekleşmesi nedeniyle bilgilerinin güncelliğinin sağlanması açısından da uygulama büyük önem taşımaktadır. Kayıtların tutulması, güncellenmesi ve paylaşılması noktasında merkezi bir kontrol biriminin olmamasından kaynaklı yönetim zorlukları gerçekleştirilen uygulama ile aşılmış ve her birimin kendi ortamında fonksiyonel bir yapı kurmasının önüne geçilerek bütünleşik bir veri tabanı odağında planlama, yönetim ve kontrol fonksiyonları etkin bir hale getirilmiştir. 


\section{KAYNAKÇA}

Akyazı, E. (2003). Organizasyonel karar destek sistemleri ve organizasyonel kararlarda bilişim sistemlerinin uygulanmasına ilişkin bir araştırma. Yayınlanmamış Doktora Tezi, Marmara Üniversitesi, Sosyal Bilimler Enstitüsü, İstanbul.

Alayoğlu, N. (2010). Rekabet üstünlüğü sağlamada insan kaynakları ve rekabet stratejileri uyumunun önemi. İstanbul Ticaret Üniversitesi Sosyal Bilimler Dergisi, 9 (17): 27-49.

Alter, S. (1999). Information systems: A management perspective. 3rd Edition. Boston: Adisson Wesley.

Çavuş, F. M. (2008). Karar verme, karar destek sistemleri ve yönetsel etkinlik. Akademik Bakış Dergisi, (15): 1-18.

Çetinyokuş, T. ve Gökçen, H. (2002). Borsada teknik göstergelerle analiz için bir karar destek sistemi. Gazi Üniversitesi Mühendislik Mimarlık Fakültesi Dergisi, 17 (1): 43-58.

Ekinci, F. (2008). Kamu personel yönetiminden insan kaynakları uygulamasına geçişin çalışanların verimliliğine etkisi. Maliye Dergisi, (155): 175185.

Filizöz, B. (2003). İnsan kaynakları yönetiminde uluslararası yaklaşım gerekliliği. Cumhuriyet Üniversitesi İktisadi ve İdari Bilimler Dergisi, 4 (1): 162 180.

Gökçen, H. (2011). Yönetim bilgi/bilişim sistemleri: Analiz ve tasarım. Genişletişmiş 2.Baskı. Ankara: Afşar Matbaacılık.

İnce, M. ve Oktay, E. (2006). Bilginin bir stratejik güç olarak önemi ve örgütlerde bilgi yönetimi. Karamanoğlu Mehmetbey Üniversitesi Sosyal ve Ekonomik Araştırmalar Dergisi, 9 (10): 15-29.

Karakaş, A. (2014). İşletmelerde personeli güçlü kılma yollarından personel güçlendirme. Dicle Üniversitesi Sosyal Bilimler Enstitüsü Dergisi, 6 (11): 79-105.

Karakütük, K. (1997). İnsan kaynakları. Ankara Üniversitesi Eğitim Bilimleri Fakültesi Dergisi, 30 (1): 115-132.

Keçecioğlu, T. ve Oktay, S. (2010). İnsan sermayesinin sayısallaştırılmasının dayanılmaz çekim gücü. Dokuz Eylül Üniversitesi Sosyal Bilimler Enstitüsü Dergisi, 12 (3): 67-86.

Koçel, T. (2013). İşletme yöneticiliği. 14. Baskı. İstanbul: Beta Basım Yayin. 
Küçükönal, H. ve Korul, V. (2002). Havayolu işletmelerinde insan kaynakları yönetimi. Afyon Kocatepe Üniversitesi Sosyal Bilimler Dergisi, 4 (2): $67-90$.

Laudon, K. C. ve Laudon, J. P. (2011). Karar vermeyi güçlendirme. Çev. Özlem Oktal. U. Yozgat (Çev. Ed.) Yönetim Bilişsim Sistemleri Dijital İşletmeyi Yönetme: İçinde 452-483. 12. Baskı. Ankara: Nobel Yayın.

Özsever, Ç., Gençoğlu, T. ve Erginel, N. (2009). İşgücü verimlilik takibi için sistem tasarımı ve karar destek modelinin geliștirilmesi. Dumlupınar Üniversitesi Fen Bilimleri Dergisi, (18): 45-58.

Rüzgar, N. ve Kurt, M. (2013). Yöneticiler aslında ne yapar? Yönetici rolleri hakkında Bursa merkezli işletmelerde bir araştırma. Işsletme Araştırmaları Dergisi, 5 (4): 35-49.

Ünnü, N. A. ve Keçecioğlu, T. (2009). İnsan kaynakları yönetiminden 'stratejik' insan kaynakları yönetimine dönüşüm. Ege Akademik Bakış Dergisi, 9 (4): 1171-1192.

T.C. Çalışma ve Sosyal Güvenlik Bakanlığı, "Asgari Ücretin Net Hesabı ve İşverene Maliyeti", http://www.csgb.gov.tr/csgbPortal/cgm.portal?page=asgari (18.09.2014).

Türkiye Bilişim Derneği (2010). Kamuda karar destek sistemlerinin kullanımı ve bir model önerisi. Türkiye Bilişim Derneği Kamu Bilgi İşlem Merkezleri Yöneticileri Birliği Kamu Bilişim Platformu XII Nihai Raporu, 3 Mayıs 2010 .

Yenihan, B. (2014). Örgütsel bağlılık ve iş tatmini arasındaki ilişki. Karabük Üniversitesi Sosyal Bilimler Enstitüsü Dergisi, 4 (2): 170-178.

Yıldız, O., Dağdeviren, M. ve Çetinyokuş, T. (2008). İşgören performansının değerlendirilmesi için bir karar destek sistemi ve uygulaması. Gazi Üniversitesi Mühendislik Mimarlık Fakültesi Dergisi, 23 (1): 239-248. 